\title{
Herbicides for Weed Control in Eucalyptus Culture ${ }^{1}$
}

\author{
Anna Osiecka and Patrick Minogue
}

\section{Introduction}

Eucalyptus is a diverse genus with over 700 species, most of which are native to Australia. Numerous Eucalyptus species and hybrid clones have been introduced in temperate climates throughout the world and grown as ornamental trees as well as for fuel and fiber. There is renewed interest in planting this fast-growing tree in the southeastern United States for mulch, pulpwood, and bio-energy.

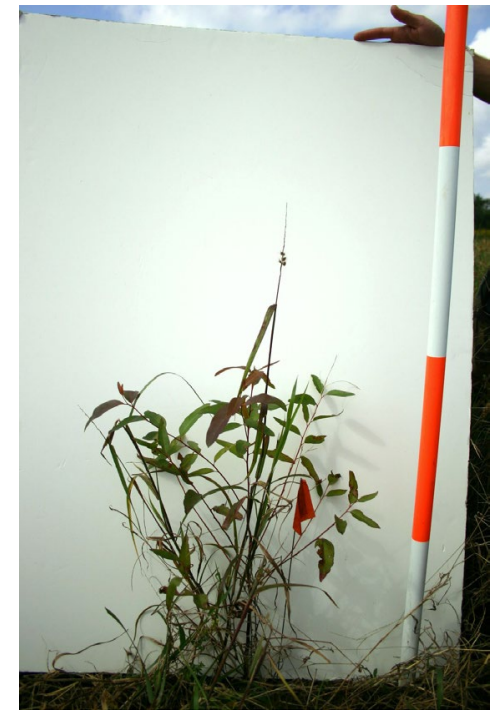

Figure 1. When grown without weed control, Eucalyptus urograndis is approximately two feet tall at five and a half months after planting in a study at Quincy, Florida.

Credits: Anna Osiecka, University of Florida
However, several silvicultural challenges exist, and competing vegetation control is a significant one.

Young Eucalyptus trees are very sensitive to the adverse effects of plant competition, especially in the initial months after planting. The photographs below illustrate the effect of weed competition on the growth of Eucalyptus urograndis five months after an April planting of six-week-old rooted cuttings in Quincy, Florida.

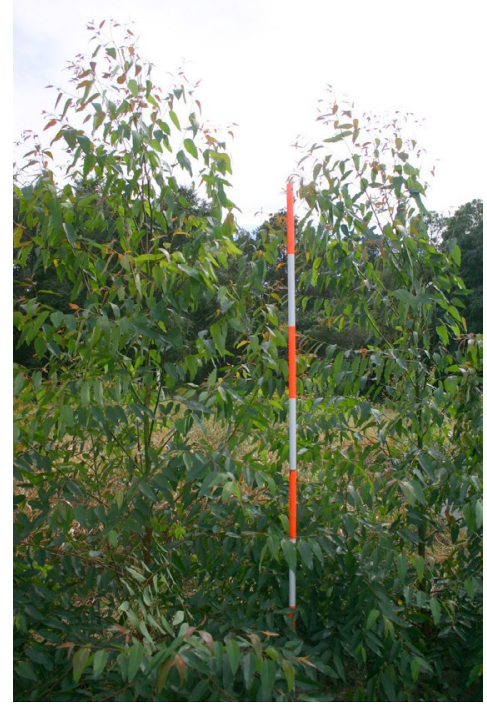

Figure 2. In the same Quincy study, E. urograndis grown with near complete weed control is nine to ten feet tall at the same age. Credits: Anna Osiecka, University of Florida

1. This document is FOR310, one of a series of the School of Forest Resources and Conservation, Florida Cooperative Extension Service, Institute of Food and Agricultural Sciences, University of Florida. Original publication date February 2013. Visit the EDIS website at http://edis.ifas.ufl.edu.

2. Anna Osiecka, senior biological scientist, School of Forest Resources and Conservation, University of Florida, IFAS, North Florida Research and Education Center, Quincy, Florida 32351; and Patrick J. Minogue, assistant professor of silviculture, School of Forest Resources and Conservation, University of Florida, IFAS, North Florida Research and Education Center, Quincy, Florida 32351.

The use of trade names in this publication is solely for the purpose of providing specific information. UF/IFAS does not guarantee or warranty the products named, and references to them in this publication do not signify our approval to the exclusion of other products of suitable composition. All chemicals should be used in accordance with directions on the manufacturer's label.

The Institute of Food and Agricultural Sciences (IFAS) is an Equal Opportunity Institution authorized to provide research, educational information and other services only to individuals and institutions that function with non-discrimination with respect to race, creed, color, religion, age, disability, sex, sexual orientation, marital status, national origin, political opinions or affiliations. U.S. Department of Agriculture, Cooperative Extension Service, University of Florida, IFAS, Florida A\&M University Cooperative Extension Program, and Boards of County Commissioners Cooperating. Nick T. Place, Dean 
Currently, directed applications of the herbicide glyphosate are widely used, but this herbicide is non-selective and requires very careful application and shielding of trees in order to avoid injuring or killing Eucalyptus plantings. Because glyphosate does not provide residual weed control, frequent repeated applications are necessary, resulting in significant costs to growers. Development of weed resistance is also an issue with repeated applications of the same herbicide.

This publication provides a list of herbicides with different active ingredients labeled for weed control in Eucalyptus plantings for various use sites (plantations, ornamentals, etc.) as described by herbicide labels (Tables 1 and 2). It gives examples of products for each active ingredient, but it is not meant to be all-inclusive. Inclusion of a product trade name in this publication does not constitute an endorsement of a product or a company because other products manufactured by different companies might be equally suited for the intended use. It must be noted, however, that two herbicides with the same active ingredient can have very different labels and use patterns. For example, Alligare SFM 75 is labeled for Eucalyptus (supplemental labeling), while DuPont Oust ${ }^{\circ}$ XP is not, even though both contain $75 \%$ sulfometuron methyl active ingredient. It is essential that the herbicide you choose is specifically labeled for Eucalyptus culture in Florida (personal communication, Charlie Clarke, Florida Department of Pesticide Registration, November 30, 2009).

\section{Guide Information}

This publication is a general guide and is not intended to provide specific treatment recommendations. The user must always read and follow the label instructions for a specific product being used. Herbicide labels are accessible at CDMS (all accessed December 5, 2012). Failure to follow the directions for use and precautions on the labels may result in poor weed control or tree injury and may be a violation of the law. The effectiveness and safety of the use of a particular herbicide in a given situation greatly depends on many factors (Osiecka and Minogue, 2011) including the Eucalyptus species, stage of growth and weeds to be controlled. If repeated applications are needed, the maximum use rate per year and the minimum interval between applications must be observed.

\section{Table 1. Herbicide Listing by Active Ingredient, Trade Name, and Use}

Table 1 lists the active ingredients, trade names and manufacturers for various herbicides labeled for Eucalyptus culture and the ranges of labeled application rates for different uses, including site preparation prior to planting, herbaceous weed control (HWC) as a directed spray (applied directly to target weeds without contacting Eucalyptus), or HWC over-the-top (OTT) of Eucalyptus using a selective herbicide to which the species is tolerant. The appropriate herbicide application rate depends on crop-tree tolerance to the herbicide and the weed species present, their stage of growth, and density. Soil characteristics such as texture and acidity $(\mathrm{pH})$ are important in determining the appropriate selective herbicide rate for those herbicides absorbed by plants from the soil (soil-active herbicides). It is always advisable to use the lowest rate that will provide an acceptable level of weed control for a specific situation.

All glyphosate products are non-selective and can be applied either for site preparation prior to planting or as a carefully directed spray to weeds after planting. Unlike other products labeled for Eucalyptus culture, glyphosate is effective in controlling established weeds, but it provides no residual control. Pre-emergent herbicides such as sulfometuron methyl may be mixed with glyphosate to provide residual weed control. However, herbicides with residual soil activity must be used according to the labeled herbicide rate and application frequency restrictions to avoid Eucalyptus injury from root uptake.

Only herbicides with physiological selectivity can be applied over-the-top of Eucalyptus trees, and their application must be carefully calibrated to ensure that the precise amount of active ingredient per acre is applied. Healthy trees, free of stress from transplanting or drought are most tolerant to over-the-top herbicides. Generally, it is advisable to wait two weeks after planting seedlings or rooted cuttings so that trees recover from the stress of transplanting before applying herbicides over-the-top. Selectivity is enhanced if the amount of spray contacting the tree foliage is minimized by using drop nozzles or off-center nozzle systems. While label directions for some herbicides, such as oxyfluorfen, state that this herbicide can be applied only to dormant trees, many labels state that applications should not be made over-the-top of Eucalyptus during the flush of new growth. Herbicide injury is more detrimental to Eucalyptus grown for ornamental purposes than to Eucalyptus grown for fiber.

Pre-emergent herbicides are soil-active, and many of these herbicides must be applied before weed emergence because they kill only germinating weeds (e.g., pendimethalin). Other pre-emergent herbicides also provide control when applied post-emergence of weeds (sulfometuron methyl), but generally the best results are obtained when weeds are 
small. Since soil-active herbicides are absorbed by plant roots, they should not be applied after Eucalyptus transplanting until soil is firmly settled around the roots. Rainfall or hand watering after transplanting will help to settle the soil. In addition, soil-active, pre-emergent herbicides must be made available in the soil solution to "activate" them after application, usually by rain or irrigation. For optimum weed control, some require quick activation (e.g., Snapshot 2.5 TG within 3 days), while others are less sensitive to degradation on the soil surface and allow for a larger window (e.g., 3-4 weeks for GoalTender ${ }^{\circ}$ ). Shallow cultivation (mixing herbicide into the upper 1-2 inches of soil) can also activate some herbicides (e.g., Snapshot 2.5 TG), while deeper cultivation after application usually reduces effectiveness because the herbicide concentration is reduced.

Post-emergent herbicides may be absorbed by the roots and foliage (e.g., sulfometuron methyl), or only by the foliage (e.g., glyphosate). Complete and uniform spray coverage on weed foliage and the addition of a surfactant may improve absorption and the performance of foliar-active herbicides. Several important selective herbicides used for weed control in Eucalyptus (sulfometuron methyl, oxyfluorfen, flumioxazin) have both soil and foliar activity and can be used either pre- or post-emergence, but applications of these herbicides are most effective when made to weeds at a seedling stage and their effectiveness diminishes as the weeds mature.

Weed composition is the first factor to consider when choosing a herbicide. Non-selective herbicides can kill a broad spectrum of weed species when used at an appropriate rate. Some selective herbicides (e.g., oxyfluorfen and sulfometuron methyl) control both grasses and broadleaf weeds at rates tolerated by Eucalyptus, while others are effective only against grasses (e.g., fluazifop-P-butyl and sethoxydim) or broadleaves (e.g., clopyralid). The effectiveness of some herbicides is limited to annual weeds, which as a rule are easier to control then the perennials. Perennial vines and woody plants are most difficult to control, and few selective herbicide options are available for Eucalyptus culture. These plants should be controlled prior to planting.

\section{Table 2. Herbicide Listing by Labeled Eucalyptus Taxa and Sites}

Table 2 provides Eucalyptus taxa for which the listed herbicides have been labeled. Some labels mention only the genus Eucalyptus, while others specify species or even cultivars. It is possible that some herbicides could be applied to other Eucalyptus species in addition to the ones listed in Table 2. However, we have observed that different Eucalyptus taxa may exhibit different tolerance to herbicides labeled generally for Eucalyptus. It is advisable to first test the herbicide on a small number of plants at a specific site and stage of growth to determine selective herbicide rates for a particular Eucalyptus variety.

Since different taxa within the genus Eucalyptus can be used for forestry or ornamental objectives, both forestry and horticultural herbicides have been included in this publication. A herbicide cannot be legally used on a site for which it is not labeled. Moreover, it cannot be used in a state for which it has not been registered. While most herbicides are registered country-wide, some have statewide exclusions (e.g., SFM 75), and others are registered in a specific state (e.g., Assure II) or even specific counties (e.g., Clopyralid 3). Therefore, it is imperative to carefully read labels before deciding on a herbicide for a specific purpose.

\section{Additional Resources}

The following Additional Resources (all accessed December 4,2012 ) can be helpful in developing herbicide prescriptions for vegetation management in Eucalyptus:

- Crop Data Management Systems (CDMS) can be searched for herbicide labels and material safety data sheets (MSDS).

- Label Search (a free service of CDMS) allows for a more advanced herbicide search following free registration.

- National Pesticide Information Retrieval System (CDMS) includes information about herbicides either currently or previously licensed for distribution and sale in each state.

- County Extension Agents at Cooperative Extension County Offices of the University of Florida, Institute of Food and Agricultural Sciences (IFAS) can be contacted with specific questions regarding herbicides.

- County Foresters of Florida Forest Service can be contacted for advice and technical assistance.

- Pesticide Information Office (PIO) at the University of Florida provides information, educational programs, and materials related to herbicides.

\section{Reference}

Osiecka, A. and P. J. Minogue. 2011. Considerations for developing effective herbicide prescriptions for forest vegetation management. University of Florida Cooperative Extension Service Circular FOR 273. 8 p. http://edis.ifas.ufl. edu/fr335 

嗃

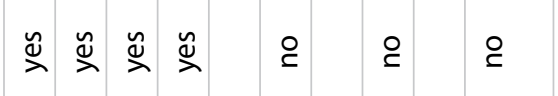

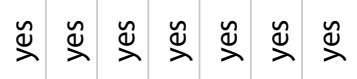
$\cong \quad$ ○
$\stackrel{\circ}{\complement}$

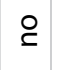

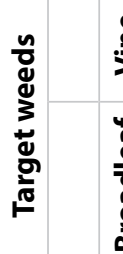

\begin{tabular}{|c|c|c|c|c|c|c|c|c|c|c|c|c|c|c|c|}
\hline$\coprod_{\beth}^{\nwarrow}$ & 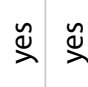 & $\stackrel{\tilde{\nu}}{>}$ & ؟ & $\stackrel{\breve{\nu}}{入}$ & $\stackrel{\circ}{\subseteq}$ & $\stackrel{\breve{~}}{\supset}$ & & & & 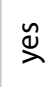 & $\stackrel{\breve{~}}{\check{\nu}}$ & 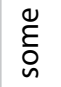 & 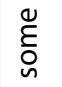 & & 窛 \\
\hline & 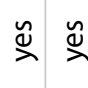 & $\stackrel{\widetilde{s}}{ح}$ & 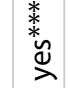 & $\stackrel{\varliminf}{\lambda}$ & \& & $\stackrel{\check{\beth}}{\curvearrowright}$ & & & & & $\stackrel{\varpi}{\lambda}$ & 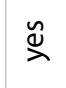 & $\stackrel{\coprod}{\lambda}$ & & $\stackrel{\coprod}{\beth}$ \\
\hline
\end{tabular}

气ั气

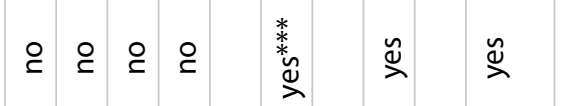

$\frac{0}{0}$

$\therefore$ 素

春豊

$\stackrel{\Perp}{\beth}$

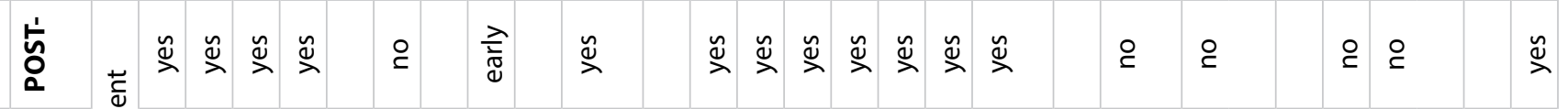

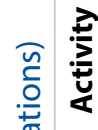

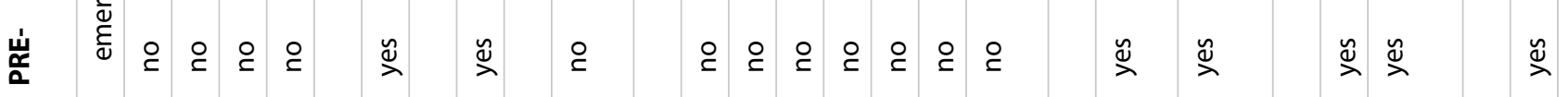

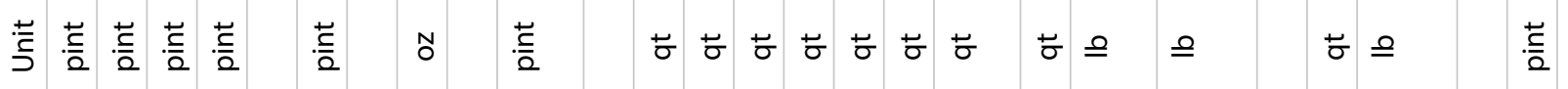

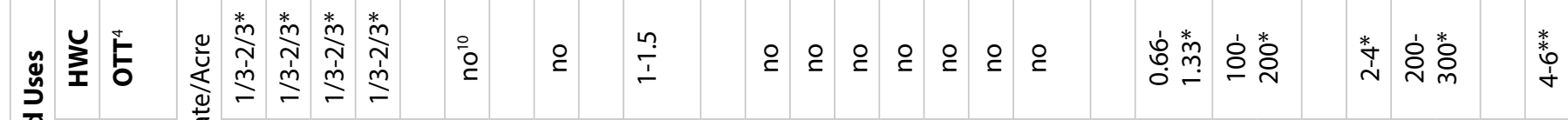

$\frac{\sqrt{d}}{\frac{10}{d}}$

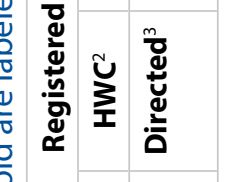

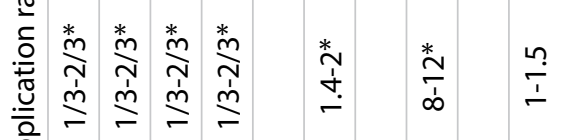

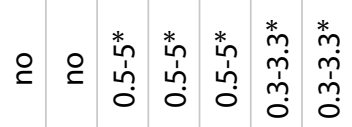

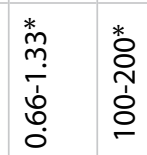

苦

$\stackrel{\varphi}{+}$

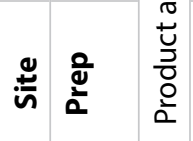

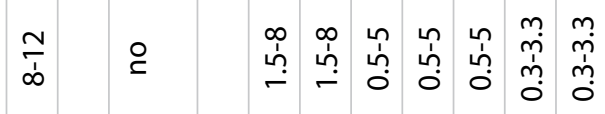

$\stackrel{\circ}{9}$

$\stackrel{\circ}{\circ}$

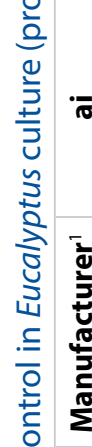

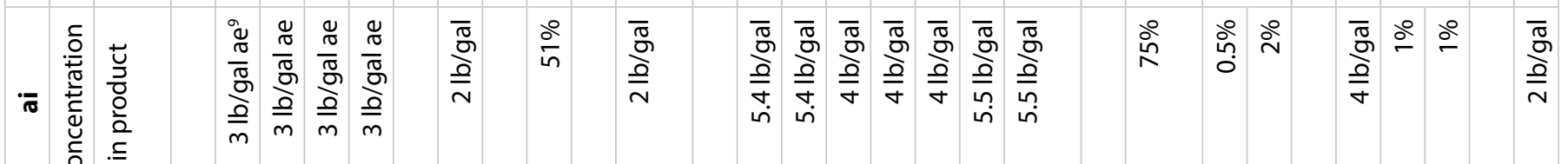

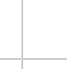

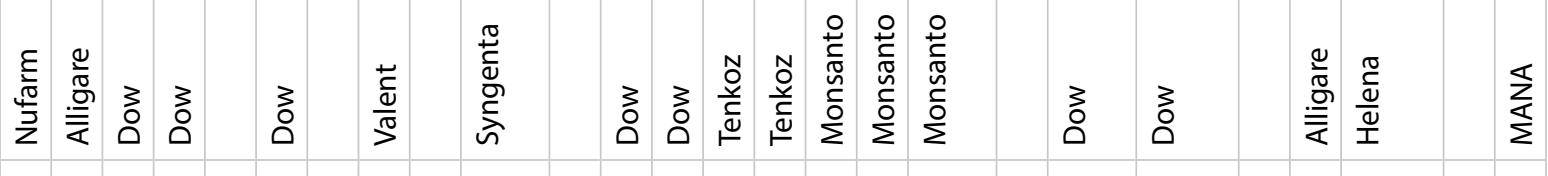

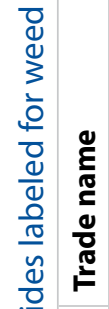
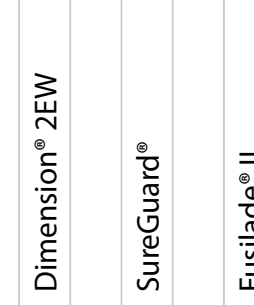

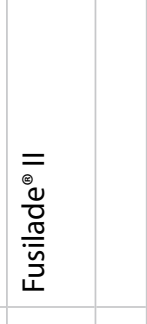
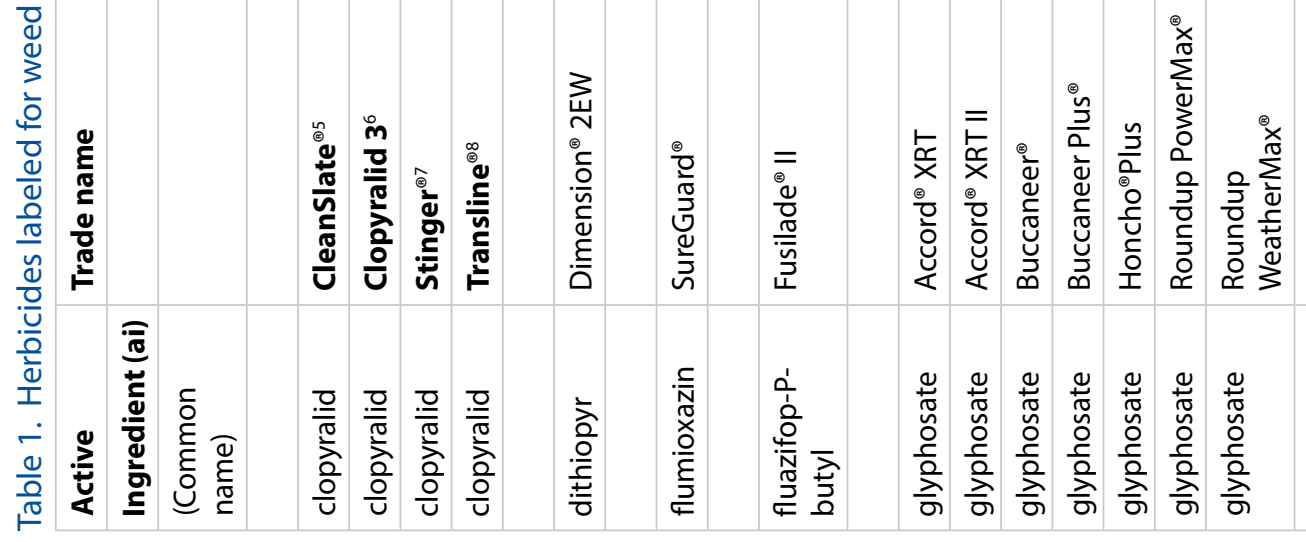

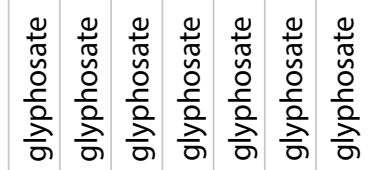

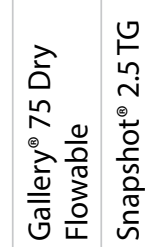

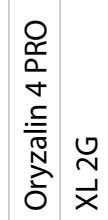

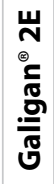




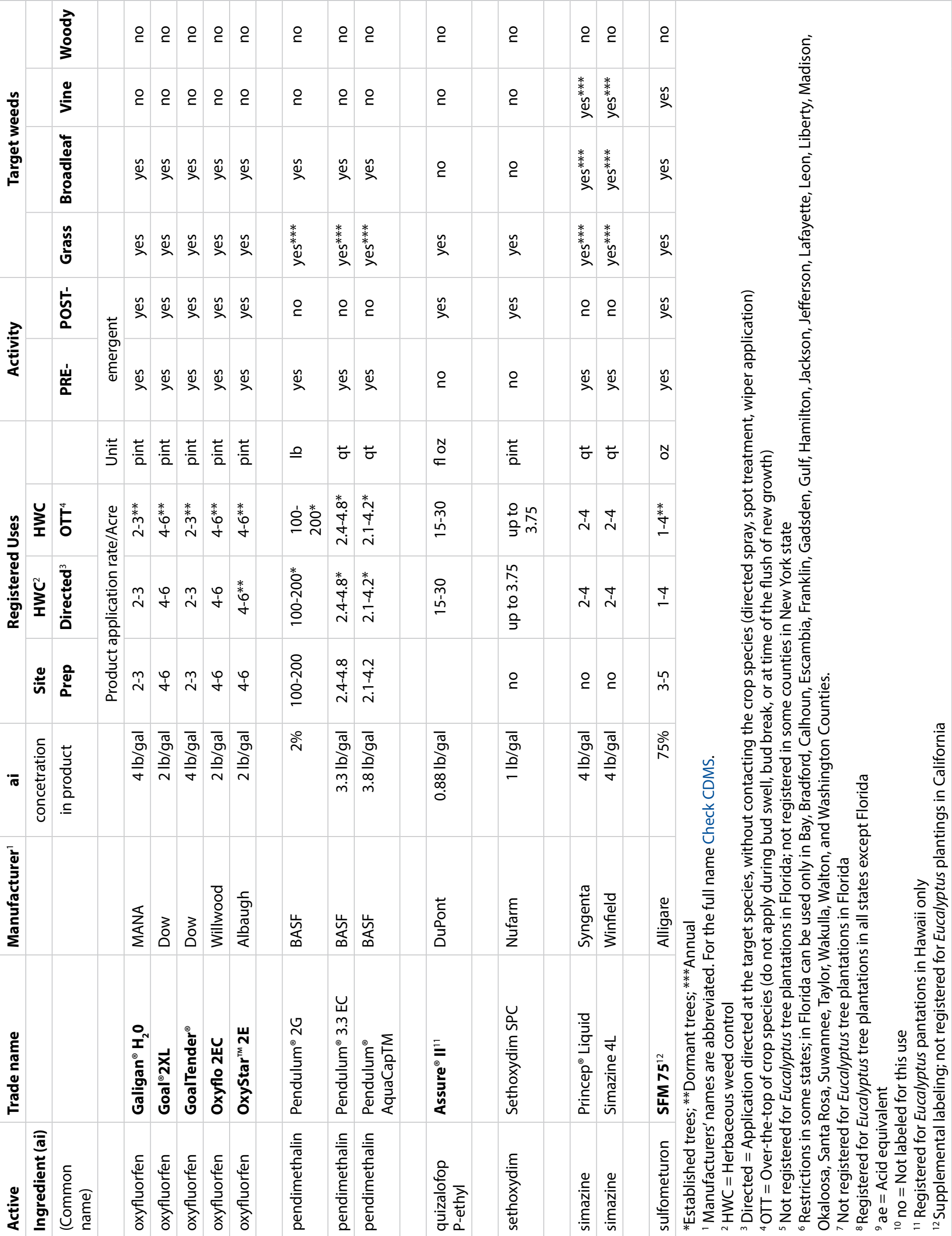


Table 2. Herbicides labeled for the culture of various Eucalyptus species at different registered use sites (products in bold are labeled for Eucalyptus plantations)

\begin{tabular}{|c|c|c|c|}
\hline Common name & Trade name & Labeled species & Labeled use sites \\
\hline clopyralid & CleanSlate $^{\circledast 1}$ & Eucalyptus spp. & Eucalyptus tree plantations ${ }^{1}$ \\
\hline clopyralid & Clopyralid $3^{2}$ & Eucalyptus spp. & Eucalyptus tree plantations \\
\hline clopyralid & Stinger ${ }^{\oplus 3}$ & Eucalyptus spp. & Eucalyptus tree plantations ${ }^{3}$ \\
\hline clopyralid & Transline $^{\circledast 4}$ & Eucalyptus spp. & Eucalyptus tree plantations ${ }^{4}$ \\
\hline dithiopyr & Dimension $^{\circledast} 2 \mathrm{EW}$ & E.citriodora & Field-grown ornamentals \\
\hline flumioxazin & SureGuard ${ }^{\circledast}$ & Eucalyptus spp. & $\begin{array}{l}\text { Field-grown deciduous tree } \\
\text { species }\end{array}$ \\
\hline fluazifop-P-butyl & Fusilade $^{\circledast}$ II & $\begin{array}{l}\text { E.microtheca, E.polyanthemos, } \\
\text { E.rostrata }{ }^{5} \text {, E.rudis, E.spathulata; } \\
\text { directed spray: E.citriodora, } \\
\text { E.nicholii }\end{array}$ & Field-grown ornamentals \\
\hline glyphosate & Accord $^{\oplus}$ XRT & Eucalyptus spp. & Forestry site preparation \\
\hline glyphosate & Accord $^{\circledast}$ XRT II & Eucalyptus spp. & Forestry site preparation \\
\hline glyphosate & Buccaneer $^{\circledast}$ & Eucalyptus spp. & $\begin{array}{l}\text { Non-food tree crops; } \\
\text { ornamentals; forestry site prep }\end{array}$ \\
\hline glyphosate & Buccaneer Plus $^{\circledast}$ & Eucalyptus spp. & Non-food tree crops; ornamentals \\
\hline glyphosate & Honcho ${ }^{\circledR}$ Plus & Eucalyptus spp. & Non-food tree crops \\
\hline glyphosate & Roundup PowerMax ${ }^{\circledast}$ & Eucalyptus spp. & Non-food tree crops \\
\hline glyphosate & Roundup WeatherMax ${ }^{\circledast}$ & Eucalyptus spp. & Non-food tree crops \\
\hline isoxaben & Gallery ${ }^{\circledast} 75$ Dry Flowable & $\begin{array}{l}\text { E.camaldulensis, E.cinerea, } \\
\text { E.microtheca, E.sideroxylon }\end{array}$ & Field-grown ornamentals \\
\hline isoxaben+trifluralin & Snapshot ${ }^{\oplus} 2.5$ TG & $\begin{array}{l}\text { E.camaldulensis, E.cinerea, } \\
\text { E.microtheca, E.sideroxylon }\end{array}$ & Field-grown ornamentals \\
\hline oryzalin & Oryzalin 4 PRO & $\begin{array}{l}\text { E.camaldulensis, E.cinerea, } \\
\text { E.nicholii, E.sideroxylon }\end{array}$ & Field grown ornamentals \\
\hline oryzalin+benefin & $X L 2 G$ & $\begin{array}{l}\text { E.camaldulensis, E.cinerea, } \\
\text { E.nicholii, E.sideroxylon }\end{array}$ & Field-grown ornamentals \\
\hline oxyfluorfen & Galigan $^{\circledast} 2 \mathrm{E}$ & $\begin{array}{l}\text { E.camaldulensis, E.pulverulenta, } \\
\text { E.viminalis, }\end{array}$ & Eucalyptus plantings \\
\hline oxyfluorfen & Galigan ${ }^{\circledR} \mathrm{H}_{2} \mathrm{O}$ & $\begin{array}{l}\text { E.camaldulensis, E.pulverulenta, } \\
\text { E.viminalis, }\end{array}$ & Eucalyptus plantings \\
\hline oxyfluorfen & Goal $^{\circledR} \mathbf{2 X L}$ & Eucalyptus spp. & Eucalyptus plantings \\
\hline oxyfluorfen & GoalTender $^{\circledR}$ & Eucalyptus spp. & Eucalyptus plantings \\
\hline oxyfluorfen & Oxyflo 2EC & Eucalyptus spp. & Eucalyptus plantings \\
\hline oxyfluorfen & OxyStar $^{\mathrm{TM}} 2 \mathrm{E}$ & Eucalyptus spp. & Eucalyptus plantings \\
\hline pendimethalin & Pendulum ${ }^{\circledast} 2 \mathrm{G}$ & E.sideroxylon 'Rosea' & $\begin{array}{l}\text { Ornamentals; tree plantations site } \\
\text { prep and maintenance }\end{array}$ \\
\hline pendimethalin & Pendulum $^{\circledast} 3.3 \mathrm{EC}$ & E.sideroxylon 'Rosea' & $\begin{array}{l}\text { Ornamentals; tree plantations site } \\
\text { prep and maintenance }\end{array}$ \\
\hline
\end{tabular}




\begin{tabular}{|c|c|c|c|}
\hline Common name & Trade name & Labeled species & Labeled use sites \\
\hline pendimethalin & Pendulum ${ }^{\circledast}$ AquaCapTM & E.cinerea, E.sideroxylon 'Rosea' & $\begin{array}{l}\text { Ornamentals; tree plantations; } \\
\text { pulpwood and fiber farms }\end{array}$ \\
\hline quizalofop P-ethyl & Assure $^{\circledR} \|^{6}$ & Eucalyptus spp. & $\begin{array}{l}\text { Eucalyptus plantations } \\
\text { (Hawaii) }^{6}\end{array}$ \\
\hline sethoxydim & Sethoxydim SPC & $\begin{array}{l}\text { E.citriodora, E.globulus, } \\
\text { E.lehmannii, E.polyanthemos, } \\
\text { E.robusta, E.sideroxylon }\end{array}$ & Trees; deciduous tree farms \\
\hline simazine & Princep ${ }^{\circledast}$ Liquid & Eucalyptus spp. & Shelterbelts \\
\hline simazine & Simazine 4L & Eucalyptus spp. & Shelterbelts \\
\hline sulfometuron & SFM 757 & Eucalyptus spp. & $\begin{array}{l}\text { Eucalyptus site preparation and } \\
\text { release }^{7}\end{array}$ \\
\hline \multicolumn{4}{|c|}{$\begin{array}{l}{ }^{1} \text { Not registered for Eucalyptus tree plantations in Florida; not registered in some counties in New York state } \\
{ }^{2} \text { Restrictions in some states; in Florida can be used only in Bay, Bradford, Calhoun, Escambia, Franklin, Gadsden, Gulf, Hamilton, Jackson, } \\
\text { Jefferson, Lafayette, Leon, Liberty, Madison, Okaloosa, Santa Rosa, Suwannee, Taylor, Wakulla, Walton, and Washington Counties. } \\
{ }^{3} \text { Not registered for Eucalyptus tree plantations in Florida } \\
{ }^{4} \text { Registered for Eucalyptus tree plantations in all states except Florida } \\
{ }^{5} \text { E. rostrata is a synonym for E. camaldulensis. } \\
{ }^{6} \text { Registered for Eucalyptus plantations in Hawaii only } \\
{ }^{7} \text { Supplemental labeling; not registered for Eucalyptus plantings in California }\end{array}$} \\
\hline
\end{tabular}

